\title{
Differentiation of surface properties of chlorococcalean algae by means of aqueous two phase systems
}

JAN BURCZYK ${ }^{1,2}$, DOROTA SZYMAKOWSKA'

${ }^{1}$ Department of Pharmacognosy and Phytochemistry, Silesian Medical Academy, Jagiellońska 4, 41-200 Katowice-Sosnowiec, Poland

${ }^{2}$ Laboratory of Applied Biochemistry, Institute of Zootechnics, Gumna 43, 43-400 Cieszyn, Poland

(Received: May 18, 1988. Accepted: October 12, 1988)

\begin{abstract}
Algal celis belonging to various strains of Chlorococcales (Chlorophyta) have been partitioned in aqueous two-phase systems containing ionogenic polymers, DEAE-dextran or SDS-dextran, at various $\mathrm{pH}$ values. Strain-specific differences of partition type which have been found in the phase systems used can be useful for distinguishing of algal cells.

Key words: Algae, aqueous two-phase system, Chlorococcales cell surface differentiation of strains
\end{abstract}

\section{INTRODUCTION}

The classification of unicellular algae, especially those belonging of the genus Chlorella (Chlorophyceae, Chlorococcales), encounters various difficulties. This is caused by the lack of suitable morphological characters in the genus Chlorella and has prompted phycologists to find other properties useful for taxonomic purposes. Useful criteria for taxonomy and classification of unicellular green algae are reviewed by Kessler (1982). The partition of cells in aqueous two phase systems can also serve as a method for distinguishing of 
unicellular algae. Partitioning of cells in such systems takes place between one of the phases i.e. the top phase (T), or the bottom phase (B) and the interphase (I). After the phases settle, part of the cells gather in one of the phases and/or in phase I. Chlorella cells of different strains treated with this method also give various distribution patterns (Albertsson 1971, Burczyk et al. 1987).

The partition coefficient or per cent of cell particles in the top phase is a consequence of the electrical potential between the phases. By this method the partition is studied as a function of $\mathrm{pH}$ for two systems with a specific composition of salts or charged polymers (one positively - and one negatively-charged). Partition coefficients of two such systems plotted against $\mathrm{pH}$ give two curves that cross each other at the isoelectric point. Such systems can be used to characterize the charge properties of algal cells. The aim of this paper was to describe the $\mathrm{pH}$-dependent partition of cells of various chlorococcalean strains in aqueous Dextran/Polyethylene glycol systems containing positively (DEAE-dextran) or negatively charged (SDS-dextran) polymers. It was interesting to find an eventual $\mathrm{pH}$-dependent cross-point formed by distinct values of partition coefficients of the DEAE- or SDS-dextran containing system. Phase systems containing the mentioned charged dextrans were used for correct identification of Penicillium strains differing in their ability to form mycotoxins. It was found that conidia of asymmetric Penicillium differed markedly in their cross-points. These last were dependent on the culture media. It seems that the crossing points are unique for individual species as well (Strom and Blomquist 1985).

\section{MATERIAL AND METHODS}

Algologically and bacteriologically clean strains, listed in Table 1 were used. Origin of strains: B - collection of the author, Institute of Zootechnics, Gumna-Ciesıyn. PL; Cz - collection of Prof. F. C. Czygan University of Würzburg (GFR); G - collection of Prof. E. G. Pringsheim, University of Gottingen (GFR); L - University of Leningrad (USSR); Li - collection of University of Liverpool (U. K.); P - collection of ČSAV, Prague (ČSSR); $\mathrm{S}-$ collection of Prof. H. Senger, University of Marburg (GFR).

All strains were grown mixotrophically under sterile conditions in Erlenmyer flasks closed with cotton plugs.

The cultures were grown in $1 \mathrm{dm}^{3}$ Erlenmeyer flasks containing $500 \mathrm{~cm}^{3}$ of modified medium I (Burczyk 1987b). The modification consists in using instead of $5 \mathrm{~g} \mathrm{dm}^{-3}$ glucose two sugars i.e. glucose and sucrose $\left(2.5 \mathrm{~g} \mathrm{dm}^{-3}\right.$ each). When the previously described medium I containing $5 \mathrm{~g}$ glucose per $\mathrm{dm}^{3}$ was used, damage of cells of some strains was observed. All mineral components of here used medium were the same as in previous paper 
Table 1

Partition patterns of various algal strains (Chlorococcales) in aqueous two phase systems with organic polymers

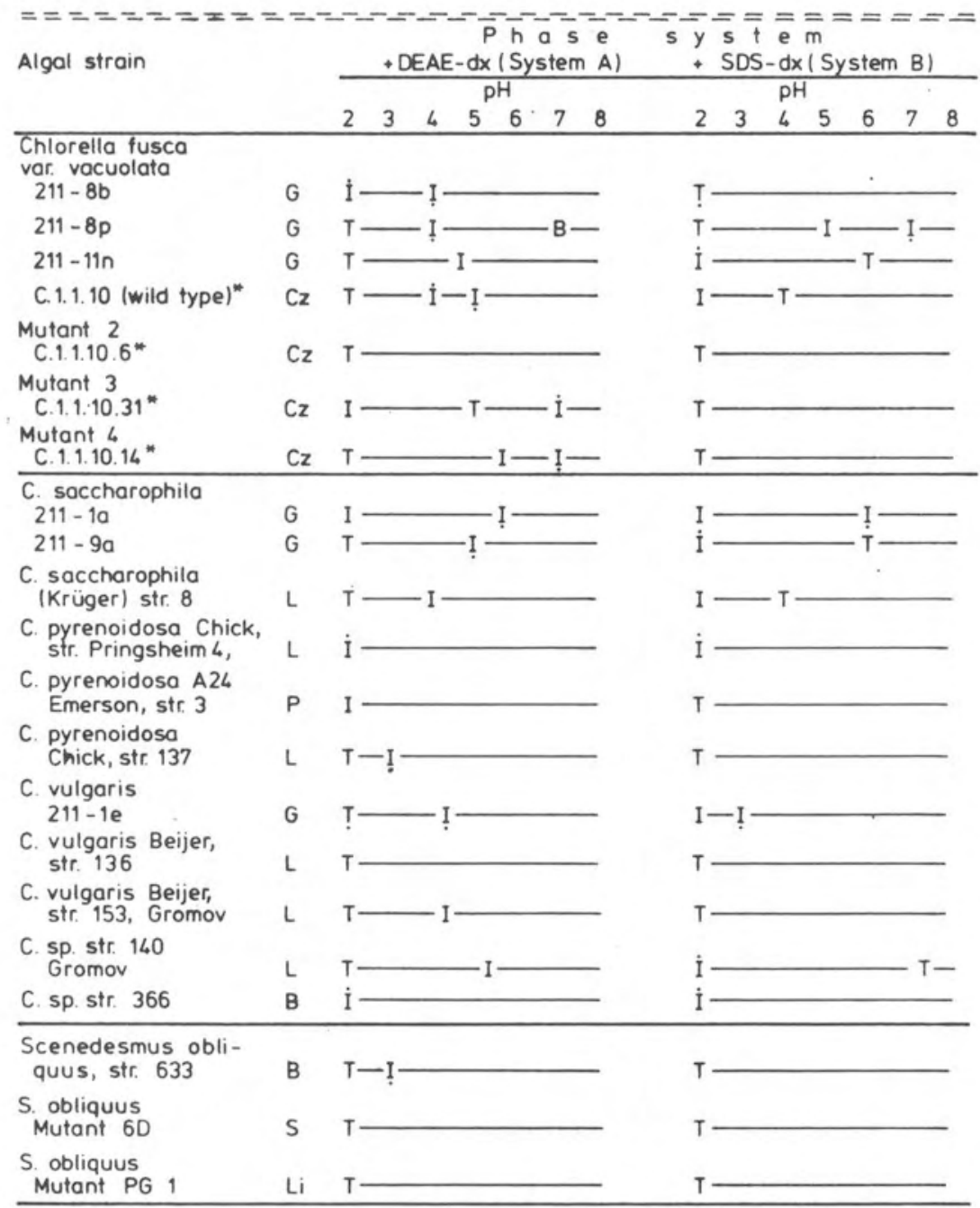

Cells prefer: $\mathrm{T}$ - top phase, $\mathrm{I}$ - interphase, B - bottom phase, $\mathrm{T}$ - with tendency to $\mathrm{I}, \mathrm{I}-\mathrm{I}$ with tendency to $\mathrm{T}, \mathrm{I}-\mathrm{I}$ with tendency to $\mathrm{B}$ phase.

* Characterized by Burczyk et al. (1981).

(Burczyk 1987b) and corresponded to medium I of Kessler and Czygan (1970).

The culturing conditions as follows: temp. $27 \pm 1^{\circ} \mathrm{C}$, illumination with fluorescent tubes at 2000 lux. The cultures were not aerated with carbon dioxide but only mixed twice a day by hand. After 30 days of growth the algae 
were collected by centrifugation at $800 \times \mathrm{g}, 10 \mathrm{~min}$. and washed 5 times by centrifuging them under the same conditions and finally used for the partition experiments.

PARTITION IN THE TWO PHASE SYSTEM

The cells were partitioned in two phase systems composed of: (A) $5 \% \mathrm{w} / \mathrm{w}$ Dextran T 500 (Pharmacia Fine Chemicals, Uppsala, Sweden), 4\% w/w Polyethylene glycol $\mathrm{M}_{\mathrm{w}} 6000$ (Union Carbide Corp., USA), 0.5\% w/w DEAE-dextran (Pharmacia, Uppsala, Sweden), $50 \mathrm{mM} \mathrm{NaCl}$ and $12.5 \mathrm{mM}$ citrate/phosphate buffer $\mathrm{pH}$ 2-8. (B) The same composition as in system A but DEAE-dextran was replaced with $0.5 \% \mathrm{w} / \mathrm{w}$ sodium-dextran-sulphate.

The influence on partition was tested by a single batch procedure (in a test tube). Each tube contained polymers forming systems A or B, $8 \mathrm{~g}$ of buffer, finally $1 \mathrm{~cm}^{3}$ of the appropriate algal suspensium in distilled water was added to obtain the above mentioned composition. Partition experiments were carried out at $17 \pm 1^{\circ} \mathrm{C}$ in vertical position and the results noted after $10 \mathrm{~min}$ settlement of phases.

\section{RESULTS AND DISCUSSION}

The partition patterns of algal cells of various strains obtained in aqueous two phase systems which contained positively charged DEAE-dextran (System A) or negatively charged SDS-dextran (System B) are presented as a function of $\mathrm{pH}$ in Table 1. Generally, it can be said that system A gave better differentiation than system B.

Two algal groups which show differences in reactivity to $\mathrm{pH}$ changes in the phase system can be distinguished. The first group is formed by strains which reacted in single step partition by pushing the algal cells from one phase to another (pushing types $\mathrm{T} \rightarrow \mathrm{I}, \mathrm{T} \rightarrow \mathrm{I} / \mathrm{B}, \mathrm{T} \rightarrow \mathrm{B}, \mathrm{I} \rightarrow \mathrm{T}$ ). The majority of strains of this group reacted with pushing type $\mathrm{T} \rightarrow \mathrm{I}$ (about $63 \%$ of strains) in system A with rising $\mathrm{pH}$ values. One of them (i.e. Chlorella fusca, strain 211-8p) even reacted with pushing type $\mathrm{T} \rightarrow \mathrm{B}$ in the $\mathrm{pH}$ range of 7-8. These pushings take place at $\mathrm{pH}$ values which are characterisitic for various strains. The second group consisted of strains which did not react at all to the changes of $\mathrm{pH}$ in both systems (I-constant or T-constant). Cells of these strains are independent of the $\mathrm{pH}$ value in the $\mathrm{I}$ or $\mathrm{T}$ phase. Examples of such strains are Chlorella pyrenoidosa 4, Ch. pyrenoidosa A 24, Ch. vulgaris 136, Chl. sp. strain 366, Ch. fusca mutant 2, Scenedesmus obliquus mutant PG 1 and mutant 6D. From the same number of investigated strains only 9 reacted by shifting in phase system B. The dominating reaction type was $\mathrm{I} \rightarrow \mathrm{T}$ by increasing the $\mathrm{pH}$. 
The results show that using different iones such as citrate or phosphate buffering the systems, chloride ions as well as larger polymeric iones i.e. DEAE-dx and SDS-dx as ionogenic polymers stronger steering particle in opposite phases no distinct cross-points which relate to partition values in isoelectric points (Ip) were observed. Such cross-points are typical for various soluble proteins and proteins on the cell surface, e.g. of Penicillium crustosum and $P$. camenbertii conditions and were used as tools to differentiate conidia of different species (Ström and Blomquist 1985).

The lack of distinct cross-points for algae belonging to the genus Chlorella and Scenedesmus (Chlorococcales) tested in this study may be explained by: (a) low net charge of surface proteins over a relatively large $\mathrm{pH}$ range and (b) high hydratation of algal cell surface rich in polysaccharides and/or glycoproteins, (c) cross-points corresponding with the Ip below pH 2.0 i.e. investigated in this paper. This last suggestion may find confirmation in Ip values estimated by microelectrophoresis for cells of Chlorella vulgaris at $\mathrm{pH} 0.85$ and Chl. pyrenoidosa at $\mathrm{pH} 1.25$ (Shherbakova 1970).

Some tendency to the pushing type T-I or IB, but not a clear crossing point, was observed only Chl. fusca, strain 211-8p as an exception.

It seems that the reacting type to $\mathrm{pH}$ changes of algal cell partition conducted in aqueous two phase systems which contain charged polymers reflects the interaction of ionogenic and hydrophobic groups of the diffusic cell surface layer with polymers and salts of the given system (W al ter et al. 1985).

It is interesting that the presence of sporopollenin-like hydrophobic polymers in the outer cell wall layer of the strains tested here, e.g. Chlorella str. 211-8b, 211-8p, 211-11n, C.1.1.10, Scenedesmus str. 633, Scenedesmus mutant PG 1 and $6 \mathrm{D}$ does not distinguish them in their reacting type from natural strains as well as from UV-induced defective mutants 2-4 (being derivatives of Chlorella fusca 1.1.10) which do not contain this biopolymer in their cell walls (Burczyk and Hesse 1981, Burczyk 1987a, b). This phenomenon may be explained by the presence of masking glycoproteins or polysaccharides on the algal cell surface. The presence of glycoproteins on the cell surface can be demonstrated by tannin solution which causes the floculation of the suspension of the outer cell wall layer (Burczyk, unpublished data).

The partition pattern of algal cells belonging to various strains of Chlorococcales grown under constant conditions in aqueous phase systems can be useful in distinguishing and identifying the strains. 


\section{REFERENCES}

Albertsson P. A., 1971. Partition of cell particles and macromolecules. Almquist and Wiksell, Stockholm.

Burczyk J., 1975. Countercurrent distribution and partition of Chlorella-sensitive and resistant strain to the lytic agent in two-phase system. I. Exptl. Cell Res. 90: 211-222.

Burczyk J., 1987a. Biogenetic relationships between ketocarotenoids and sporopollenins in green algae. Phytochemistry 26: 113-119.

Burczyk J., 1987b. Cell wall carotenoids in green algae which form sporopollensis. Phytochemistry 26: $121-128$.

Burczyk J., Hesse M., 1981. The ultrastructure of the outer cell wall-layer of Chlorella mutants with and without sporopollenin. Plant Syst. Evol. 138: 121-137.

Burczyk J., Zontek I., Szurman N., 1978. Partition of various algal strains in two-phase system of dextran and polyethylene glycol. Bull. Acad. Polon. Sci. 26: 745-750.

Kessler E., 1982. Chemotaxonomy in the Chlorococcales. In: Progress in phycological research. Vol. 1, Round Chapmaned, Elsevier Biomedical Press, B. V., pp. 112-135.

Kessler E., Czygan F-Ch., 1970. Physiologische and biochemische Beiträge zur Taxonomie der Gattung Chlorella. IV. Verwertung organischer Stickstoffverbindungen. Arch. Mikrobiol. 70: 211-216.

Ström G., Blomquist G., 1985. Classification of fungi by means of cross-partition in aqueous two-phase systems. p. 61, Materials of the 4th Int. Conf. on Partition in Aqueous Two-Phase Systems, 18-23 August, Lund.

Shherbakova G. J., 1970. Izmienienie dzeta-potencjala klietok Chlorelli pri razlichnykh sostojanjakh kultury. Elektron. Obrab. Materialov 4: 72-74.

Walter H., Brooks D. E., Fisher D., 1985. Partitioning in aqueous two-phase systems. In: Theory, methods, uses and applications to biotechnology. Academic Press, Harcourt Brace Jovanovich Publishers, Orlando-San Diego-New York-Austin-London-Montreal-Sydney-Tokyo-Toronto.

\section{Zróżnicowanie wlasności powierzchni komórek glonów w dwufazowych systemach wodnych}

\section{Streszczenie}

Rozdziały komórek glonów różnych szczepów (Chlorococcales, Chlorophyta) w wodnym układzie dwufazowym zawierającym jonogenne polimery, tj. DEAE-dekstran lub SDS-dekstran są uwarunkowane od wartości pH. Stwierdzone różnice rozdziałów w układzie fazowym o zdefiniowanym składzie chemicznym mogą być wykorzystane do scharakteryzowania i rozróżniania szczepów trudnych do zróżnicowania na podstawie kryteriów morfologicznych. 